\title{
Resumo
}

Estuda como discursos e práticas higienistas guiaram a produção habitacional e redefiniram o ambiente doméstico na cidade de Campina Grande (PB) das décadas de 1930 e 1940. Investiga como as exigências dos códigos sanitários por ar e luz no interior das construções e a inserção do maquinário urbano de saneamento estabeleceram novas diretrizes para o exercício projetual e contribuíram para a legitimação das profissões de engenheiro, arquiteto e urbanista perante a sociedade brasileira dos anos 1930. Através do estudo de caso do município do interior da Paraíba, busca compreender a abrangência das políticas sanitárias e habitacionais vigentes no Estado Novo

Palavras-chave: produção habitacional, higiene, Campina Grande (PB).

1 Este artigo é uma versão reduzida e revisada de parte do capítulo 2 da dissertação de mestrado intitulada "Quem te vê não te conhece mais: arquitetura e cidade de Campina Grande em transformação (1930-1950)", defendida em agosto de 2008 no Programa de Pós-Graduação da EESC-USP, sob a orientação da Prof. Dra. Maria Ângela Bortolucci e com o auxílio da FAPESP (processo $N^{\circ}$. 05/52920-0). o início do século passado, os anúncios publicados nos jornais da cidade de Campina Grande, interior da Paraíba, nos dão a medida de como os conhecimentos e as novas sensibilidades acerca da higiene e as recentes noções de conforto permeavam o seu cotidiano. O Sabão Hygienico Protector, a Barbearia Popular e a Valet Auto Strop cuidavam do corpo; a Confeitaria Petrópolis esterilizava suas louças e matinha sempre renovado seu sortimento de frutas; os hotéis ofereciam alimentação cuidadosamente confeccionada, banheiros higiênicos, aparelhos sanitários e aposentos magnificamente arejados. Embora já correntes em cidades brasileiras desde os oitocentos, o arejamento constante e a iluminação natural dos ambientes domésticos e de trabalho e a mecanização das construções eram novidades para aquela Campina Grande recém apresentada à modernidade. As heranças dos séculos anteriores não trouxeram o hábito de abrir janelas para a iluminação e a ventilação dos dormitórios, o abastecimento de água e a coleta dos esgotos eram, em grande parte, ainda manuais e equipamentos como bacias sanitárias eram pouco acessíveis no começo dos 1930. O simples aparecimento de questões como aeração de ambientes e utilização de bacias sanitárias na

\author{
Marcus Vinicius Dantas de Queiroz \\ Arquiteto e Urbanista (CAU/UFPB), mestre (PPGAU IAU/USP), \\ docente do Curso de Arquitetura e Urbanismo da Universidade \\ Federal de Campina Grande, Rua Aprígio Veloso, 882, Bloco \\ CM, Bairro Universitário, Campina Grande, PB, CEP 58429-140, \\ (83) 2101-1773, marcusvidanq@gmail.com
}

publicidade da época como sinônimos de qualidade e distinção nos dá a medida do quanto eram exceção naquele contexto.

O movimento sanitarista vigente no início de século XX agiu no sentido de "convencer e educar o homem comum para comportamentos individuais e coletivos fundados no conhecimento da medicina existente" (HOCHMAN, 1998, p.80). Isto significava "modificar práticas e hábitos sociais arraigados, como o consumo de álcool, a prostituição, a nãoutilização de calçados e latrinas, o despejo de lixo em rios e vias públicas, a manutenção de focos de moscas, ratos e mosquitos, a fraude no leite e nos alimentos" (HOCHMAN, 1998, p.80). A busca pela higiene foi um movimento de reforma da vida cotidiana, formador do homem moderno do século XX e promotor de sensações burguesas de conforto e intimidade, como as do sweet home inglês (ANDRADE, 1992, p.17). Assim, da mesma maneira que a busca por uma cidade sanitária alterou seus usos, formas de organização e infraestrutura, as construções passaram por significativas transformações para se adequarem a um ideal de salubridade e conforto, promotoras de um cotidiano 
2Cf. Beguin, 1991 higiênico para usuários e moradores. Era a extensão, para a esfera privada, de uma série de intervenções ocorridas nos espaços públicos. Arejar e iluminar os ambientes, deixá-los longe dos esgotos e abastecê-los com água potável tornaram-se questões de saúde pública e também de economia².

As campanhas sanitaristas da época estabeleciam diretrizes nesse sentido. Prescreviam diversos cuidados que as pessoas deveriam ter com os seus corpos e dejetos que induziam a novos procedimentos de produção e utilização dos edifícios: "beber agua fervida ou filtrada e leite sómente fervido"; "não usar gelo directamente n'agua ou no que quizer gelar, por que os microbios da febre typhoide e paratyphoide podem existir no gelo, desde que a agua com que foi fabricado este não tenha sido filtrada"; "manter as latrinas sempre bem limpas e só usar papel hygienico"; "si apparecer um doente dessas molestias em casa, deve ser ele isolado, escolhendo-se para isto, na falta de isolamento publico, um dos melhores commodos na propria residência, que tenha janellas para fora, a fim de receber ar e luz directos"; " não esquecer de lavar as mãos, com água e sabão, antes das refeições", "as fézes e urinas devem ser misturadas com qualquer desinfectante ou cal commum, postas nas latrinas ou enterradas" (PRECAUÇÕES..., 1935; DIRECTORIA..., 1935).

A busca por um modelo de habitação considerado sadio e moralizado foi um dos principais eixos de debate, e de efetiva ação, acerca da reestruturação da cidade moderna. A preocupação com a casa salubre, principalmente para as massas pobres, permeou praticamente todas as ações sanitárias engendradas por médicos e técnicos desde o século XIX. Engenheiros, utopias urbanas oitocentistas e arquitetos modernistas se sucederam na reprodução de práticas e discursos. Resgatando falas anteriores, as discussões do IV Congresso Internacional de Arquitetura Moderna, registradas na versão corbusiana da Carta de Atenas do início dos 1940, buscava nas informações médicas subsídios científicos e legitimados para a condenação dos modelos correntes de moradias urbanas. Em uma de suas passagens, concluiu que a tuberculose se instalava onde não havia incidência solar. Portanto,

[...] o sol deve penetrar em toda a moradia algumas horas por dia, mesmo durante a estação menos favorecida. [...] A sociedade não tolerará mais que familias inteiras sejam privadas de sol e, assim, condenadas ao definhamento. [...] É preciso exigir dos construtores uma planta demonstrando que no solstício de inverno o sol penetrará em cada moradia no mínimo 2 horas por dia. Na falta disso será negada a autorização para construir. Introduzir o sol é o novo e o mais imperioso dever do arquiteto (LE CORBUSIER, 1993).

Os Congressos Pan-americanos de Arquitetos, realizados entre 1920 e 1940, discutiram questões semelhantes. Os de 1920 e 1923, realizados, respectivamente, em Montevidéu e Santiago do Chile, concluíram que os governos e as instituições particulares deveriam incentivar a construção de habitações higiênicas e baratas, cujos terrenos destinados para esse fim teriam que ser "dotados de serviço sanitário, luz e pavimentação". Solicitaram das municipalidades e das repartições de obras sanitárias das nações e dos Estados a modificação dos regulamentos de construções vigentes "adaptando-os ás necessidades economicas requeridas pelos trabalhos sanitarios, alturas de habitação e exigencias menos dispendiosas, afim de obter economia em sua execução, sem infligir as regras de higiene, segurança e estética dos edifícios". Os arquitetos também chamaram a atenção dos municípios para que fomentassem "a edificação estimulando em contrario dos interesses privados, a manutenção de jardins e grandes pateos que assegurem a bôa aeração e insolamento das construções". Para as habitações insalubres já presentes nas cidades, ordenaram suas reparações ou, para os casos mais graves, suas demolições. Por fim, declararam que

[...] para obter um criterio definido nas condições de nossas vivendas que tanta influencia têm na saude fisica e moral do povo, para assegurar a beleza, segurança e higiene de toda a especie de edificios, é indispensavel regulamentar a profissão de Arquiteto baseada nesse titulo outorgado e reconhecido pelo Estado, determinando as atribuições proprias e privativas dessa profissão que é a unica capaz de dar solução exata a esses problemas [...] da vida moderna (CONGRESSO..., 1940, p.13-18).

A Comissão do Aspecto Higiênico do $1^{\circ}$ Congresso Pan-americano de Vivenda Popular, realizado em Buenos Aires no ano de 1939, cuja comitiva brasileira 
era formada majoritariamente por engenheiros, recomendou que

[...] os governos incorporem na sua legislação disposições que no menor tempo possível, facilitem a eliminação total dos casebres insalubres existentes nos perímetros urbanos e que por meio de uma politica sanitaria proceda a demolição desses "arremedos de casas", impondo tributos e limitando as taxas de alugueis, não permitindo a construção de vivendas, nem a venda ou subdivisão de lótes, em zonas não urbanizadas ou não urbanizaveis (CONGRESSO..., 1939, P.67).

Os discursos de arquitetos e engenheiros reproduziam uma série de diagnósticos e recomendações largamente conhecidos e praticados desde o século anterior, com todas as suas descrições médicocientíficas e visões preconceituosas acerca da moradia do pobre. As críticas eram para as conseqüências materiais e não as causas sociais do problema. As falas voltavam-se, em boa parte, contra o mercado de habitações precárias para locação, produzidas pela iniciativa privada para atender à demanda das camadas pobres que acorriam às cidades. A oferta era de moradias de baixa qualidade construtiva, implantadas no menor espaço possível, visando o máximo aproveitamento dos lotes para o maior lucro do empreendedor. Considerava-se tal implantação, somada a outros aspectos, como a ausência de aberturas e os baixos pés-direitos, responsável pela condição anti-higiênica das construções, pois dificultava ou impedia que, aí, circulasse ar e incidisse luz solar. Para os congressistas, só o Estado, com seu amplo poder de alcance, com a sua função de prezar pelo interesse público e com sua capacidade de estabelecer e de fazer cumprir as leis, seria capaz de atuar incisivamente na solução do problema da habitação insalubre. Os caminhos possíveis seriam a elaboração de legislações que arbitrassem sobre a qualidade e a localização das construções, o incentivo fiscal à moradia higiênica ou medidas radicais e autoritárias, como a demolição dos "arremedos de casa".

Assim como garantir a aeração, a conquista da luz solar no interior das construções foi apontada como a nova preocupação dos arquitetos. Dessa forma, prever recuos em relação às edificações vizinhas, inserir pátios, poços, jardins e aberturas em todos os cômodos, regular a cubagem dos ambientes de acordo com suas áreas e altura dos pés-direitos e calcular cientificamente a quantidade de luz solar recebida diariamente pelas edificações passaram a ser rotinas obrigatórias para arquitetos e demais projetistas, devidamente previstas nos códigos de obra e controladas, com maior ou menor rigor, pelas repartições de obra e de higiene das municipalidades. A conformação do ambiente doméstico salubre também pressupunha que a casa deveria surgir em via pavimentada, drenada e atendida pelas redes de saneamento, para as quais o edifício teria que estar tecnicamente adaptado. Eram preocupações inéditas, pelo menos na obrigatoriedade e na escala de suas repercussões, introdutoras de outras variáveis no exercício da concepção projetual e de rupturas com os padrões construtivos e urbanísticos de herança colonial, dominantes no Brasil até boa parte dos oitocentos.

Para garantir as eficiências técnica e estética de todas essas transformações nas moradias, e, conseqüentemente, na cidade, promovendo, assim, "a saude fisica e moral do povo", os arquitetos se colocavam como os únicos profissionais capazes de dar a solução exata aos problemas da vida moderna. Para tanto, mobilizavam-se numa campanha próregulamentação do exercício profissional pelo Estado, o qual deveria determinar as "atribuições proprias e privadas dessa profissão". Os arquitetos faziam coro com os discursos e as reivindicações dos engenheiros do final do século XIX e começo do $X X$, os quais, "assumindo os ideais de uma ciência pragmaticamente comprometida com o progresso material e moral do país, orientada para sua integração na humanidade desenvolvida, 'positiva'", mobilizavam-se pelo reconhecimento social da profissão (KROPF, 1994, p.210). Os engenheiros, assim como os arquitetos, reivindicavam "perante as elites dirigentes maiores espaços para a atuação profissional e o acesso a cargos diretivos da vida pública", denunciando "a concorrência dos chamados práticos ou charlatães, ou seja, dos mestres-de-obras que desenvolviam atividades que segundo eles deveriam caber exclusivamente aos profissionais 'cientificamente preparados'" (KROPF, 1994, p.219). No Brasil, as campanhas culminaram com a publicação do Decreto No 23.569 de 11 de dezembro de 1933, durante o governo Vargas, que regulamentou as profissões de engenheiro, arquiteto e agrimensor. Era a legalização das profissões de um país que se desejava urbano. 
Com maior ou menor intensidade, todas essas questões afloraram e tiveram repercussões simultâneas no interior paraibano, nesse momento de formação da cidade moderna brasileira. As empreitadas para higienizar a moradia, dotando-a de ar, luz e de todo um aparato técnico para sua conexão às recentes redes mecanizadas de saneamento, a reforma ou a demolição de habitações precárias distribuídas no perímetro citadino, a elaboração de legislações para o arbítrio e o controle das maneiras de se construir e a exigência de projetistas devidamente legalizados junto aos Conselhos de Engenharia e Arquitetura para a concepção das edificações foram responsáveis por alterações significativas nas formas urbanas da cidade de Campina Grande.

Pretende-se, portanto, discutir nesse artigo as transformações por que passaram a arquitetura e o espaço do morar do município paraibano ao longo das décadas de 1930 e 1940, engendradas por um corpo técnico-científico de médicos, engenheiros e arquitetos que problematizaram a cidade a partir de uma perspectiva higiênica.

\section{Porcaria, nojo, repugnância...}

A preocupação com a salubridade das moradias não era uma novidade da Campina Grande dos 1930. Em 1890, um artigo publicado no jornal $A$ Gazeta do Sertão, assinado por França Júnior, dizia que a alcova deveria receber

ar vivificante em suficiente abundancia e se desembarace daquelle que, por já ter servido, se viciou. A parte da casa que deve occupar mais attenção dos que se interessam pela saude de seu semelhante é o quarto de dormir. Já pelos progressos que tem feito nestes últimos tempos, não na nossa architectura, que infelizmente ainda não temos, mas o nosso systema de construir, progressos devidos em grande parte á influencia do elemento italiano que tão bons fructos vai introduzindo no Brasil, já por noções exactas da hygiene, a alcova, isto é, o quarto sem janellas, e por conseguinte sem ar e sem luz, que figura ao lado da sala de visitas ou de jantar das antigas construcções, tende a desapparecer. Felizmente. A alcova, com a lamparina de fetido azeite em cima da velha commoda de jacarandá, atravancada de uma quantidade innumera de objectos cobertos de espessas camadas de pós; com dois, três leitos, sem contar as esteiras que se estendiam a noite sobre o assoalho a apodrecer em contacto immediato com o solo, e onde dormiam o pai, a mãi [sic] e os filhos, respirando, de envolta com as exhalações de roupas sujas e dos residuos da pelle de cada um, o ar viciado pelas excreções gazosas de todos aquelles pulmóes juntos, a alcova foi o antro escaro onde a nossa raça se abastou. Dentre os casos de tuberculose pulmonar que figuram nos obtuarios fluminenses, póde-se dizer que trinta por cento têm por origem a alcova (apud AGRA, 2006, p.67-68)

Tais palavras eram ressonâncias de discussões de maior amplitude, que problematizavam a cidade a partir de questões de segurança e higiene e que viam a moradia insalubre das camadas populares como local "impróprio à saúde e à virtude; como lugar sujo e desconfortável, propício à geração de doenças e à transmissão de epidemias ao restante da população da cidade; como ambiente imoral e promíscuo, que corrompia seus moradores" (CORREIA, 2004, p.1-4). Longe do contexto campinense do século XIX, e até do XX, o texto de França Júnior era, muito provavelmente, como sinaliza, a reprodução de algum artigo publicado na então Capital Federal, mostrando-nos como os discursos da higiene e os seus vínculos com questões morais circularam e foram apropriados país afora. Às formas arquitetônicas, do meio, era imputado o processo do adoecimento. Para o autor do artigo, a arquitetura deveria progredir em prol da conquista de um ambiente saudável para seus moradores, promovendo a evolução das qualidades construtivas e a inserção de aberturas para a entrada do ar vivificante e de luz solar nas edificações. Citava, para tanto, as influências dos imigrantes italianos na arquitetura brasileira, que tão "bons fructos vai introduzindo [...] já por noção exactas da hygiene".

Na década de 1930, versões do mesmo discurso ganharam contornos mais adaptados ao contexto local. Com o acelerado crescimento demográfico desde o início do século, fruto do dinamismo econômico proporcionado pela instalação da ferrovia, as falas se voltavam contra o adensamento das partes centrais da cidade por habitações precárias, denunciavam a falta de higiene, de moral e de estética de tais construções, condenavam seus aspectos construtivos e chamavam a atenção para as poucas condições de higiene das moradias produzidas pela iniciativa privada para locação. 
3 Em 10 de dezembro de 1947, a Câmara Municipal de Campina Grande aprovou o Projeto de Lei $N^{\circ} .12$ para "a construção de casas populares nesta cidade", [...] "contemplada pela Fundação da Casa Popular". A FCP foi o "primeiro órgão federal destinado especificamente à produção habitacional no Brasil, instituída em 1946 e extinta com a criação do BNH (Banco Nacional de Habitação) em 1964" (MANOEL, 2004).
Pobreza, promiscuidade, feiúra e sujeira foram características comumente associadas às deficientes condições de moradia das prostitutas da cidade, numa reprodução de falas que poderiam ser encontradas em qualquer outro jornal país afora. Em 1931, por exemplo, o jornal Brasil Novo publicou artigo contra as "rameiras" que moravam na região central, mais precisamente no largo da luz, em

[...] uns casebres que a gíria denominou de "caixas de fósforos". O apelido não traduz o que eles são. Era necessário um cognome que significasse porcaria, nojo, repugnância, e tudo o quanto o dicionário possui com essa significação. De fato, são uns casebres de taipa, pendidos uns sobre os outros, inclinados para o solo, como pedindo um empurrão que Ihes joguem por terra. E desafiam o senso estético dos responsáveis pelo embelezamento da nossa urbe. Há dois anos que se anunciam a demolição almejada, mas os dias passam e os casebres ficam. [...] Elas, porém, gargalham pelas suas portas imundas, contra "poussê", que Ihes mingua o terreno. Mulheres sórdidas continuam morando lá, e por ser uma artéria movimentada, exibem aos transeuntes, a sua miséria e a sua porcaria. Quase todas meretrizes de baixo calão, de vestes porcas e imundas, repugnam, pelo exibicionismo de suas mazelas. Sabemos dos intuitos do sr. Prefeito [Lafayete Cavalcanti], de embelezar a Travessa da Luz, demolindo tal "cortiço". Aplaudimo-lo e lembramoIhe que a medida é de emergência. Aquilo se tolera em subúrbio, não no centro de uma cidade como a nossa (CAIXAS..., 1931).

Ainda em 1931, o mesmo jornal se engajou no movimento que a "imprensa livre" vinha fazendo em todo Brasil, desde que tomou posse o presidente Getúlio Vargas, "contra alugueres excessivos, arrancados do povo pelos desabusados proprietários de casas". Em Campina Grande, "os pobres inquilinos que, além de pagarem um aluguel exorbitante", eram "obrigados a limparem as casas ou do contrário velas-ão [sic] transformadas em verdadeiras pocilgas. Nem ao menos uma vez por anno se dignam a limpar e retelha-as".

E quando chove enchem-se de agua causando vexames e enfermidades aos que tem a desventura de habital-as. Nessa situação se encontra grande quantidade de casas de aluguer [sic] nessa cidade. Existem alguns proprietarios que, por amor a hygiene, mandam limpar as suas casas de aluguel de anno em anno, mas em cada limpesa que efectuam augmentam os alugueres (ALUGUERES..., 1931).

A tensão entre o mercado de locação e setores da sociedade não foi algo exclusivo aos grandes centros. Em outra escala e em contexto específico, a problemática vivida por Campina Grande era a mesma do que as demais pesquisas descrevem para as maiores cidades brasileiras, o que não é de se estranhar, visto que a política habitacional do país era a mesma. Com o reduzido capital das classes média e baixa e com a inexistência de financiamentos governamentais para a aquisição da casa própria, fruto da política liberal que predominou ao longo da Primeira República, a demanda por habitação era atendida pelas construções de aluguel produzidas pela iniciativa privada, denominadas por Bonduki (1998) de produção rentista. Tal situação permaneceu praticamente inalterada até 1942 , quando a promulgação da Lei do Inquilinato, pelo governo Vargas, congelou o preço dos aluguéis e arrefeceu a produção rentista, aliada ao novo elemento da promoção estatal de habitação para as classes trabalhadoras ${ }^{3}$ e ao estímulo ao auto-empreendimento da casa própria para a baixa renda.

As questões que envolvem o mercado locatário e o financiamento estatal de moradia são mais abrangentes e complexas do que o leque de discussões propostas para este artigo. O que nos interessa saber é que a maioria da população, principalmente a classe pobre e a nascente classe média, era formada por inquilinos à mercê de um mercado privado de locação, que agia livremente, sem qualquer controle ou regulamentação governamental. A produção dessas moradias primava pela economia de materiais e de espaço, levando à utilização de componentes construtivos de baixa qualidade e ao máximo aproveitamento dos lotes, características que quase sempre comprometiam as condições de higiene das habitações. Casas geminadas, sem janelas, com paredes e pisos úmidos, baixos pésdireitos e precárias instalações sanitárias (latrinas, chafarizes, tanques para lavar roupa) se espalharam pelas cidades brasileiras em crescimento. Na grande quantidade de habitações coletivas (cortiços, casas de cômodo), a situação era agravada pela superlotação e pelo limitado número de instalações sanitárias compartilhadas por vários domicílios. O preço dos aluguéis era ditado pelas regras de mercado, sem 
qualquer proteção para o inquilino e sempre a favor dos proprietários, beneficiados por uma demanda maior do que a oferta, alimentada pelo rápido crescimento demográfico urbano. O quadro só começou a ser alterado com a aprovação dos códigos de higiene (que passaram a exigir instalações sanitárias compatíveis com o número de moradores e recuos para a iluminação e ventilação dos ambientes - em alguns lugares do Brasil, isso aconteceu ainda no final dos oitocentos), com os incentivos fiscais concedidos pelos governos para a promoção da dita habitação higiênica barata e com a atuação incisiva das repartições de higiene.

Em Campina Grande, a situação não foi diferente. Até o início dos 1930, a habitação de aluguel para a classe média era a construção de alvenaria, sem recuos laterais e frontal, quartos sem janelas e latrina no fundo do prédio ou do quintal, implantadas em seus lotes estreitos e compridos. Para os mais pobres, a modalidade predominante era a casa de taipa, precária e sem qualquer instalação sanitária, construídas, muitas vezes, ao longo de ruas inteiras para a renda de seus proprietários. Distribuídas por todos os recantos do perímetro urbano, na década de 1930 elas desafiaram "o senso estético dos responsáveis pelo embelezamento da nossa urbe" (CAIXAS..., 1931). Em 1929, o jornal O Século, discorrendo acerca da remoção das prostitutas que habitavam casas de taipa erguidas na região central, falou da impossibilidade da ação em virtude de uma crise habitacional vivida pela cidade ${ }^{4}$.

4 A publicação do SESC do começo dos anos 1960 (Campina Grande: um centro comercial do Nordeste), voltou falar da crise habitacional da cidade. Disse que "embora seja intenso o ritmo de construções, há deficit em casas de aluguel". Comentou que tais habitações eram geralmente construídas por pessoas egressas da atividade comercial ou industrial, "que nisto empregam algum capital e disto vivem". As casas, de maneira geral, eram de padrão médio ou inferior, e se espalhavam por toda a cidade. Os inquilinos eram "de preferência operários, comerciários e industriários" (SERVIÇO..., 196?, p.37)
Mas, aonde o Snr. Prefeito, iria accommodar tanta gente, noutro ponto da cidade, caso desejasse levar a effeito esse magnifico plano de saneamento social, dada a crise de habitação de que a cidade vive sempre a lamentar? Não é fácil a tarefa dessa mudança por que tanto anseiam, naturalmente, os moradores que se avisinham do bulicio nocturno do Roi Couro, e de outras artérias menos roedeiras... U'a mudança em massa de uma parte de nossa população, que figura nos computos habitativos da cidade, em cifras respeitaveis, de uma zona em que já radicaram os seus habitos e costumes e onde todos já estão localizados, para outra incerta e que não reuna quantidade sufficiente de conforto domestico, sera também um desastre (PARAÍSO..., 1929).
A opinião do jornal era controversa. Ao mesmo tempo em que tratava a expulsão das prostitutas da região central, com a demolição das suas respectivas casas de taipa, como uma questão de saneamento social, preocupava-se com o desastre que seria remover as habitantes, de considerável número, segundo o jornal, de uma área onde já possuíam seus hábitos e costumes radicados para regiões inóspitas, sem "quantidade sufficiente de conforto domestico", fora do centro e sem infraestrutura urbana. A preocupação foi em vão. Em 1931, durante a administração do prefeito Lafaiete Cavalcanti, o meretrício, com suas casas ditas inestéticas, nojentas e repugnantes, foi deslocado para as proximidades dos currais, no bairro das Piabas (atual região da feira central), longe dos olhares de moradores e transeuntes do centro. Pelo próprio uso que faziam da área, currais para a comercialização de gado, é de se imaginar que tal local não era dotado de condições mínimas do tal conforto doméstico reclamado. Habitadas por prostitutas ou não, a imposição de reformas ou a demolição autoritária foram os tons utilizados pela administração municipal para a eliminação das casas de taipa do perímetro urbano. Essas medidas quase sempre foram respaldadas pelos diagnósticos emitidos pelas repartições municipais de higiene e legalizadas pelas novas imposições dos códigos urbanísticos locais.

\section{Ar e luz vivificantes}

Com alguns órgãos fortalecidos e outros organizados no final dos 1920, o aparato sanitário montado em Campina Grande agiu em várias frentes em prol da conquista de um meio urbano salubre (vacinação de pessoas e animais, inspeção de alimentos, eliminação de mosquitos causadores da febre amarela, limpeza urbana etc.). Coube à recém criada Inspetoria Municipal de Higiene (IMH), em parceria com a Diretoria Municipal de Obras Públicas, a fiscalização sobre as condições de salubridade das habitações já construídas e a serem edificadas. No segundo caso, seus técnicos passaram a deferir ou a indeferir as solicitações para construção na cidade de acordo com as qualidades higiênicas exigidas nos códigos urbanísticos municipais e previstas nos projetos arquitetônicos apresentados. 

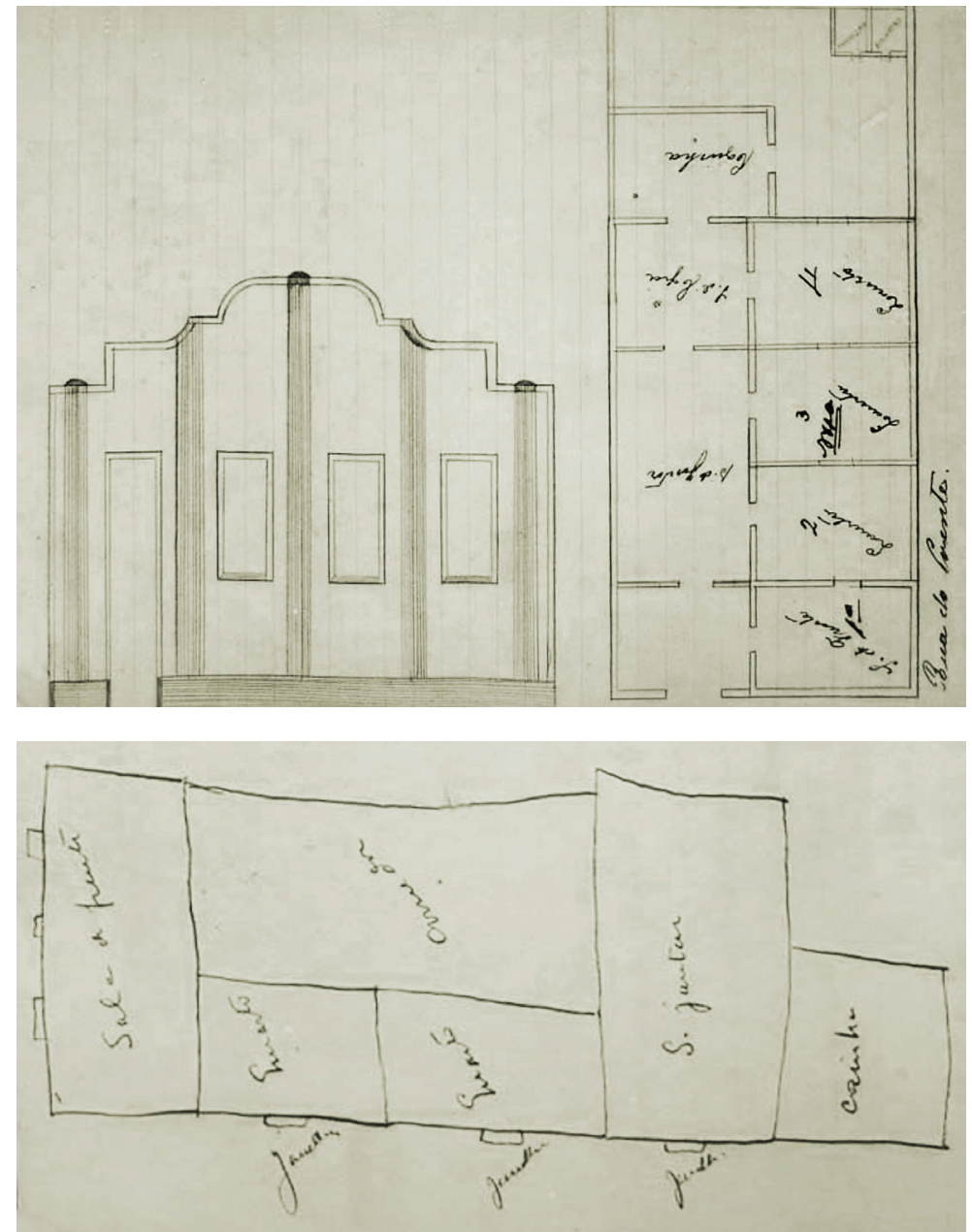

Figura 1: Pedido para a reconstrução da residência de Maria Inez de Freitas Ramos, rua do Poente, 1932. Fonte: Arquivo Público Municipal de Campina Grande (APMCG).

Figura 2: Pedido para a construção da residência de Manoel Borges de Lima, rua Santo Antônio, 1932. Fonte: APMCG.
Embora existam algumas referências de ações anteriores, como a obrigatoriedade do uso de fossa (1924), a expulsão de casas de taipa do centro (1931) e o aparecimento do inspetor de higiene aprovando ou não os pedidos para construção encaminhados à Prefeitura (1932), só foi nas solicitações de licença para se edificar em Campina Grande apresentadas a partir de 1933 que o poder público municipal surgiu arbitrando com maior rigor sobre os aspectos físicos das construções, visando controlar suas condições sanitárias. $\mathrm{Na}$ época, o prefeito era o médico Antônio Almeida, engajado na campanha pró-saneamento da cidade. No mesmo ano de 1933, surgiu um novo elemento em relação ao ano anterior no cenário local: o projeto arquitetônico, formulado segundo preceitos técnicos, elaborado não só por arquitetos, mas também por engenheiros e desenhistas devidamente licenciados pela prefeitura e registrados nos conselhos regionais de regulamentação profissional. Não por acaso, foi em 1933 que se instalou, até onde temos notícia, o primeiro escritório de arquitetura da cidade, do arquiteto Isaac Soares. Suplantando gradativamente os esquemas de plantas desenhados por mestresde-obras ou pelos próprios proprietários (imagens 1 e 2), a apresentação de projeto arquitetônico se transformou em uma ferramenta fundamental para a fiscalização das imposições construtivas, estéticas e higiênicas previstas nas legislações municipais e almejadas nessa busca pela modernização da cidade.

Para efetivar o controle sobre o espaço urbano, e o seu grau de ação, os códigos municipais dividiram Campina Grande em zonas urbana ( ${ }^{\mathrm{a}}$ zona), suburbana ( $2^{\mathrm{a}}$ zona) e rural ( $3^{\mathrm{a}}$ zona) (figura 3 ). $\mathrm{Na} 1^{\mathrm{a}}$ zona, era obrigatório apresentar projeto de arquitetura de acordo com as normas estabelecidas. 
5 Solicitação de licença para reconstrução de casa. Rua João Pessoa. Proprietário Manoel Ferreira de Barros. 1936. Fonte: Arquivo Público Municipal de Campina Grande (APMCG). Solicitação de licença para construção de alicerce. Rua Idelfonso Souto Maior. Proprietário José Honorato. 1937 (APMCG).

6 Solicitação de licença para construção de casa de taipa. Rua da Matança. Proprietário ilegível. 1936 (APMCG).

Figura 3: Mapa de Campina Grande, 1943. Cor de rosa: zona urbana. Verde: zona suburbana. Linhas ocres: estradas em direção às fontes d'água e às fazendas do município. Pontos pretos ao longo das linhas ocres: casas de taipa construídas na zona rural. Fonte: Desenhado a partir de mapa elaborado pelo Serviço Geográfico do Exército do Brasil.
Em 1936, Manoel Ferreira de Barros pediu licença para reconstruir a casa № 634 da rua João Pessoa. A Prefeitura respondeu que a licença seria concedida desde que Manoel apresentasse projeto regular, pois a área estava dentro do perímetro urbano do município. Já em 1937, José Honorato tentou construir um alicerce na rua Idelfonso Souto Maior, mas seu pedido foi indeferido, como tantos outros, porque sua obra estava na $1^{\text {a }}$ zona, e "esta zona obriga a apresentação de projecto, mesmo no caso de construção de alicerce" ${ }^{5}$.

Na $2^{\circ}$ zona, as exigências eram parecidas, porém cumpridas com rigor relativo. Um pobre que já possuísse um pequeno terreno nas áreas de subúrbio agora enriquecidas (com infra-estrutura de água esgoto e pavimentação) e valorizadas não podia mais, ali, construir sua casa simples. O pedido era indeferido. Nessas áreas, só havia espaço para as novas residências surgidas recuadas dos limites dos seus vastos lotes, erguidas de acordo com todos os requisitos para a boa higiene das construções.
Nos subúrbios mais pobres, a casa até podia ser de taipa e alinhada com a rua, mas a frente e o primeiro cômodo tinham que ser de tijolos, com projeto de fachada e, em alguns casos, obedecendo a condições mínimas para a aeração e a iluminação de ambientes. Foram muitos os projetos desse tipo apresentados à Prefeitura (imagens 4, 5 e 6).

Na zona rural, as construções eram livres de normas, e, portanto, não havia a necessidade de apresentação de projeto. A não ser em alguns casos, como o da rua da Matança, nos quais a Prefeitura exigia obediência ao "alinhamento geral" ${ }^{6}$. Foram inúmeros os casos de pedidos de licença para a construção de casas de taipa na zona rural do município, nos quais a Prefeitura a concedia por estar a futura edificação em área "fora de zoneamento"7.

Quando requisitado, o projeto deveria seguir os artigos 45 e 46 da Lei 32 de 1927, os quais determinavam que seu responsável técnico teria que ser licenciado pela Prefeitura para a exploração do

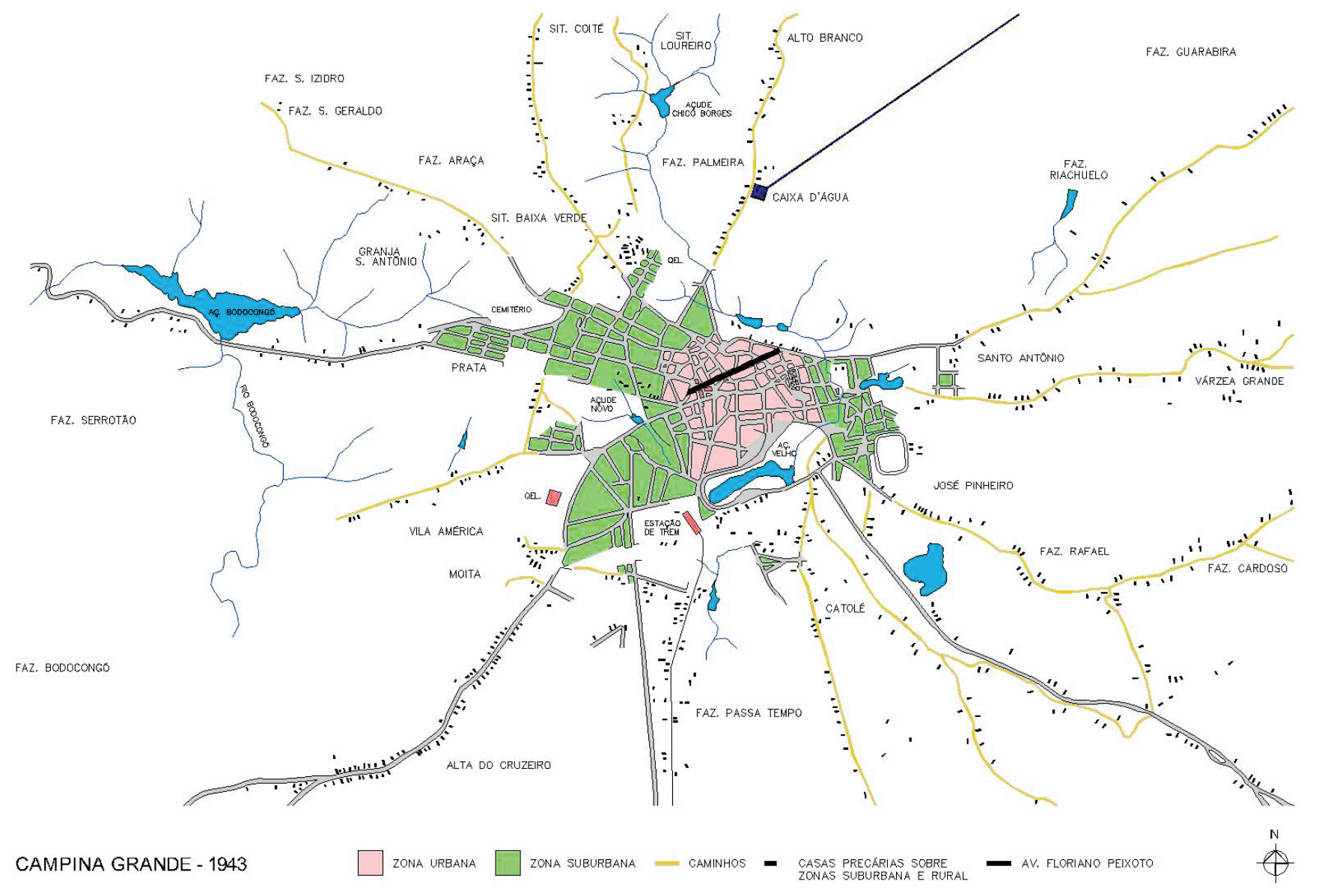



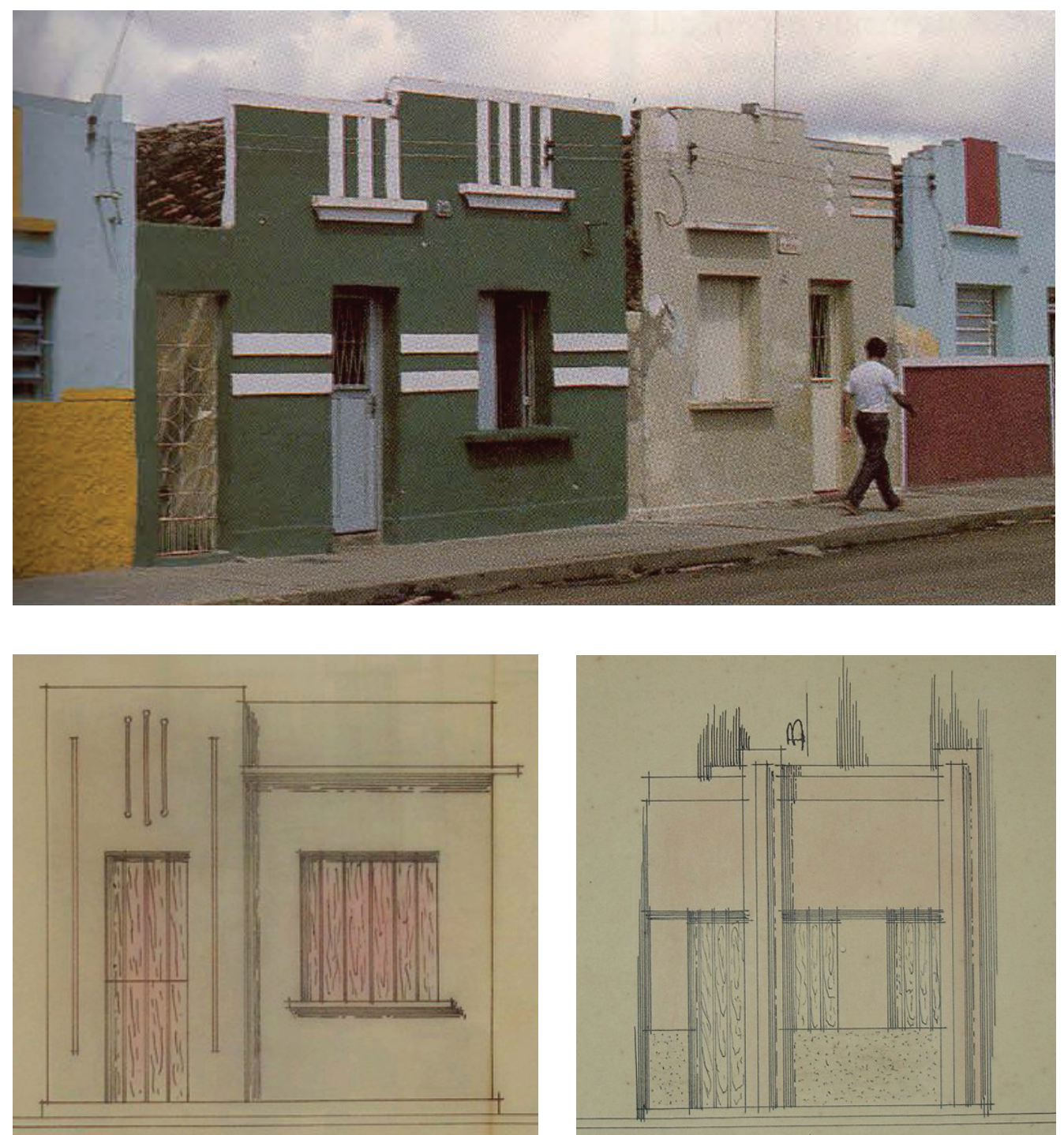

Figuras 4, 5 e 6: Casas típicas dos subúrbios mais pobres ( $2^{a}$. Zona), erguidas nos limites do lote. Alinhamento com a rua, primeiro cômodo de tijolos, projeto de fachada e condições mínimas de higiene eram as exigências para esse tipo de construção. Quando existentes, os pequenos recuos entre as edificações (becos) tinham como função oferecer alguma possibilidade para a iluminação e a aeração dos ambientes. Fontes: Rossi, 1994. Casa para a avenida Progressista, projeto do desenhista Antônio Henriques, 1936 (APMCG). Casa para o bairro da Prata, 1936 (APMCG). exercício profissional na cidade. A partir de 1935, começa a aparecer nas solicitações de licença de obra a exigência por profissional habilitado pelo Conselho Regional de Engenharia e Arquitetura, tal como rezava o Decreto Federal $N^{\circ}$. 23.569, de 11 de dezembro de $1933^{8}$.

Com toda essa lista de imposições, o poder público municipal criou as ferramentas para o controle da produção do espaço urbano campinense, seguidas com certo rigor. O projeto arquitetônico, como projeção futura do espaço a ser construído, agiu como documento probatório das intenções dos construtores, que, uma vez aprovados e rigorosamente cumpridos, garantiriam as condições sanitárias mínimas exigidas. Quanto a esse rigor no cumprimento do projeto, a municipalidade não deixou de lembrar: em 1936, quando o Sr. João do Matto pediu licença para construir sua residência na rua Almeida Barreto, na $2^{a}$ zona, o diretor de obras a concedeu desde que o alinhamento fosse cumprido e o projeto "rigorosamente respeitado" 9 . O mesmo aconteceu com Silva de Mello, também em 1936, que deveria construir sua casa, na rua Otacílio de Albuquerque, "no novo alinhamento dado pela prefeitura", respeitando "cegamente o projeto aprovado" 10 .

Dessa forma, os códigos de postura e de obra, aliados à fiscalização exercida pelas Inspetoria de Higiene e Diretoria de Obras municipais, trouxeram uma série de imposições que transcenderam o controle apenas 
7 Solicitação de licença para construção de casa de taipa. Rua Bella Vista (Bairro da Estação). Proprietário ilegível. 1936 (APMCG).

8 Solicitação de licença para construção de casa. Rua Antenor Navarro. Proprietário Josimar Albuquerque [?]. 1935 (APMCG).

9 Solicitação de licença para construção casa. Rua Almeida Barreto. Proprietário João do Matto. 1936 (APMCG).

10 Solicitação de licença para construção casa. Rua Otacílio de Albuquerque. Proprietário Silva Mello. 1936 (APMCG).

11 Solicitação de licença para construção de residências. Rua 4 de Outubro. Proprietário ilegível. 1933 (APMCG).

12 Solicitação de licença para reconstrução de prédios. Travessa Lindolpho Montenegro. Propriedade de Chryatino [?] Montenegro. 1932 (APMCG).

13 Solicitação de licença para liberação de habitações interditadas por inadequações higiênicas. Travessa da Luz. Propriedade de Manoel Idelfonso de Oliveira Azevedo. 1933 (APMCG).

14 Solicitação de licença para construção casa. Rua José Carlos. Proprietário Antônio Barboza de Mello. 1936 (APMCG). Solicitação de licença para construção casa. Rua Solon de Lucena. Proprietário Francisco Castro [?]. 1936 (APMCG). Solicitação de licença para reforma casa. Rua Vigário Calixto. 1936 (APMCG). Solicitação de licença para construção casa. Logradouro ilegível. Proprietário João Aragão. 1936 (APMCG).

15 Solicitação de licença para construção de quartos. Sem identificação de logradouro. Proprietário Manoel da Silva. 1934 (APMCG). dos elementos construtivos que possuíam alguma relação direta com o espaço público (alinhamento com a rua, altura das fachadas, proporção de aberturas e sacadas, continuidade dos telhados), como fora anteriormente em muitas cidades brasileiras. Atuando sobre a disposição dos cômodos, mensurando suas áreas, alturas e aberturas, definindo seus acabamentos e recuos em relação às construções vizinhas, a busca pela higiene criou legislações urbanas que foram de encontro ao direito à inviolabilidade da propriedade particular e que intervieram significativamente sobre as formas de se morar nas cidades, alterando não só os seus espaços privados, mas também as relações entre o edifício e o urbano.

Em Campina Grande, assim como aconteceu em outros lugares Brasil afora, além da invasão dos guardas de higiene (os mata-mosquitos) para a eliminação dos mosquitos causadores da febre amarela, a privacidade e o direito de propriedade das habitações tiveram que se adequar às normas de salubridade, principalmente quando destinadas à locação. Para as construções já existentes, a Inspetoria de Higiene condenou as consideradas insalubres, expulsando-as dos espaços centrais da cidade ou exigindo que seus proprietários fizessem os devidos reparos para se adequarem aos padrões de higiene exigidos. Percorrendo as solicitações de licença para edificação na cidade ao longo do nosso período de estudo, é muito comum encontrar pedidos como o do proprietário

[...] de um terremno[sic] na Rua 4 de Outubro numeros 198, 202 e 206, onde tem umas cazinhas de taipa vem perante $V$ sa. pedir licença para edificar novas cazas no local, sendo estas de tijollo e obedecendo as exigencias de higiene da Prefeitura, fazendo-as com area de luz para a sala de jantar e um quarto central como mostra a planta junta ${ }^{11}$.

O abaixo assignado, querendo reconstruir os predios que foram condennados pela Hygiene Municipal, à Travessa Lindolpho Montenegro, de propriedade de Chryatino [?] Montenegro, vem pelo presente pedir a V.S. se digne conceder para tal fim a devida licença $^{12}$.

Diz o Des. Manoel Idelfonso de Oliveira Azevedo

[...] que tendo desapparecido os motivos que deram logar á interdicção de seis casinhas de sua propriedade sitas na Travessa da Luz, desta cidade, visto ter feito os reparos, caiação e pintura das mesmas, e destinando á habitação apenas a que tem gabinete sanitário, vem requerer á V.S. que se digne providenciar no sentido de ser levantada a aludida interdicção, ouvido o Delegado da Hygiene Municipal ${ }^{13}$.

Nos projetos para novas construções, sempre apareciam recomendações do tipo: "Apresente o desenho de fachada a tinta e o croquis a lapis da planta para se examinar as condições de ar e luz"; "Não alterar o projecto. Fazer clarabóia"; "Apresente projecto de fachada, e dê luz directa e ar no predio"; o uso de "veneziana é obrigatorio porque a zona é urbana"14. Alguns proprietários, além de apresentar projeto dentro das normas, enfatizavam no requerimento de licença que a nova edificação receberia ar e luz, como foi o caso de Manoel da Silva, que solicitou "licença para construir nos fundos dos prédios ns 322 e 326, 12 \{doze\} quartos, sendo seis (6) inferiores, e seis superiores com área descoberta, para efeito de luz direta e ar, de acordo com a planta que junta $[\ldots]^{15}$. Assim, foi essa busca pela incidência direta de ar e luz no interior das edificações, para iluminar e ventilar principalmente os dormitórios, a maior responsável pela ruptura nos padrões construtivos campinenses na década de 1930, majoritariamente herdeiros, até então, dos padrões coloniais.

Das áreas de expansão até os espaços de ocupação mais antiga da cidade, grande parte das construções novas e reformadas incorporou recuos, jardins, terraços, varandas, janelas em todos os ambientes, pátios e poços de iluminação. Por conseqüência, as plantas ganharam arranjos mais recortados e os telhados tiveram que se adequar a desenhos mais complexos. Com as possibilidades abertas por todos esses elementos, a volumetria e o aspecto geral das fachadas passaram a ser mais explorados, com a utilização de telhados desencontrados, platibandas em níveis diferentes, beirais, marquises, jardineiras, gradis em aberturas, muros e portões. Os avanços técnicos e construtivos advindos com a revolução industrial ganharam maior espaço de recepção.

Com algumas construções surgidas em meados dos 1920, mas em multiplicação acelerada só a partir de meados dos 1930, as casas erguidas nas zonas de expansão mais abastadas se caracterizavam 
Figura 7: A garagem implantada nos fundos do lote era o mais novo item das vivendas abastadas. Como acesso, era utilizado o recuo lateral. Residência para José Branco Ribeiro, rua Desembargador Trindade, projeto do arquiteto licenciado Isaac Soares, 1935. Fonte: APMCG. pela presença de recuos frontais e/ou laterais. Isso possibilitou a circulação de ar entre as edificações, configurando o que Saturnino de Brito (1944, p.123) chamou de quarteirão salubre. Foi uma ruptura com a continuidade do quarteirão de herança colonial dominante no município. Como afirmou Andrade (1991, p.61) para o urbanismo sanitarista praticado por Brito, "rompendo o tecido conectivo da cidade tradicional, o lote planejado e higiênico" introduziu "a descontinuidade da forma urbana, característica marcante da cidade moderna".

Refletindo a riqueza dessa camada da população, os programas se tornaram mais complexos, burgueses, com a criação de espaços distintos para cada função: salas de costura, de música, de almoço e de jantar, gabinete, copa, despensa, quarto de empregada, hall, biblioteca, vestiário e mais de um banheiro, alguns já com acesso pelo interior das residências. Mesmo com esse avanço, os banheiros ainda se localizavam nos fundos das construções, colados às cozinhas ou aos quartos dos empregados. Em alguns poucos casos, os banheiros já ficavam no pavimento superior das residências. Com a criação da Comissão de Saneamento, em 1936, as novas construções já deveriam ser pensadas de acordo com as possibilidades abertas por essas redes. A garagem era o mais novo item das vivendas ricas, construída nos fundos do lote, utilizando, como acesso, largo recuo lateral (figura 7). A casa, afastada da via, dos vizinhos e das misturas das ruas tradicionais, cercada por jardins e com uma diversidade de espaços para o descanso, o trabalho e o lazer de seus moradores, estava imbuída de outra noção de privacidade,
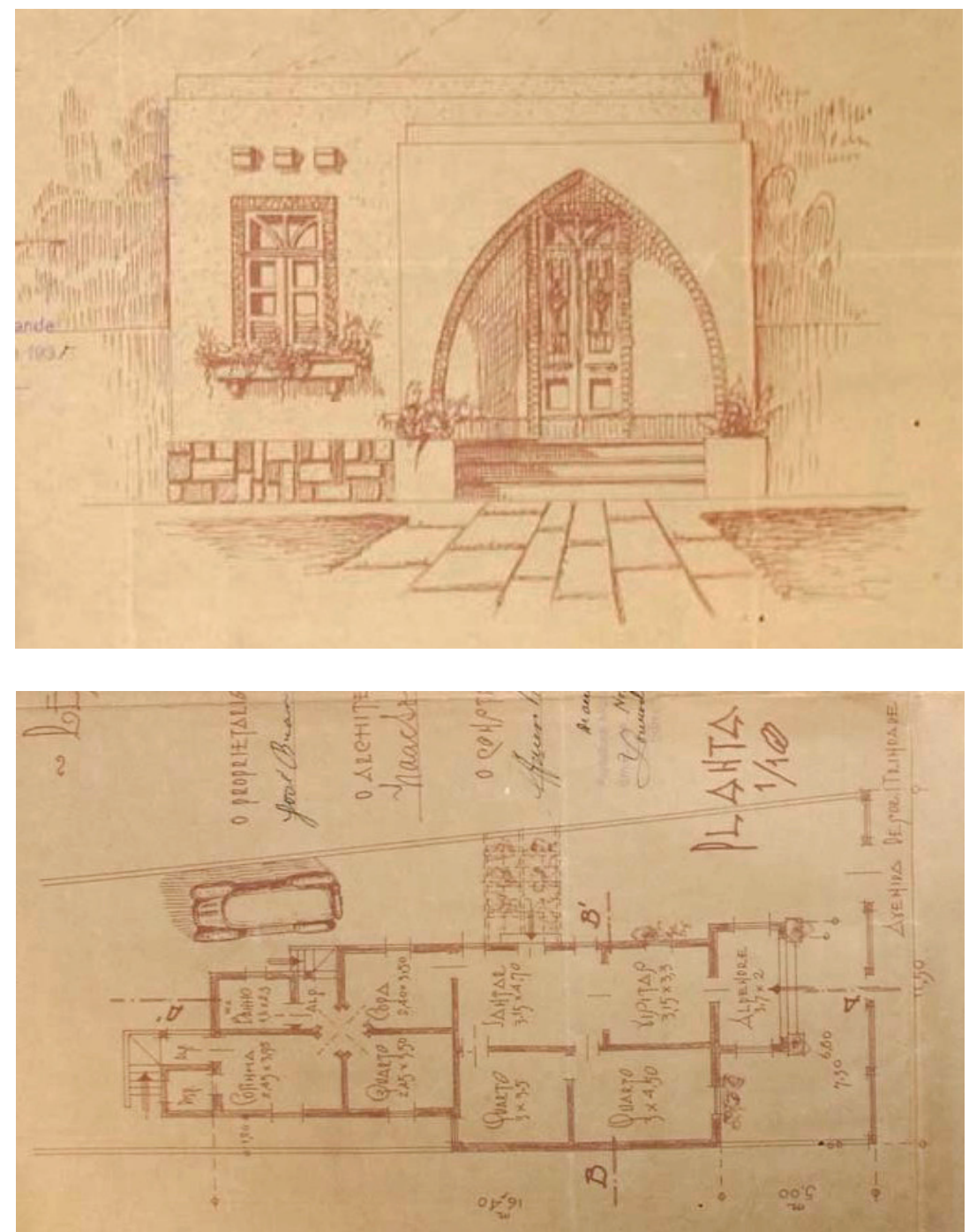

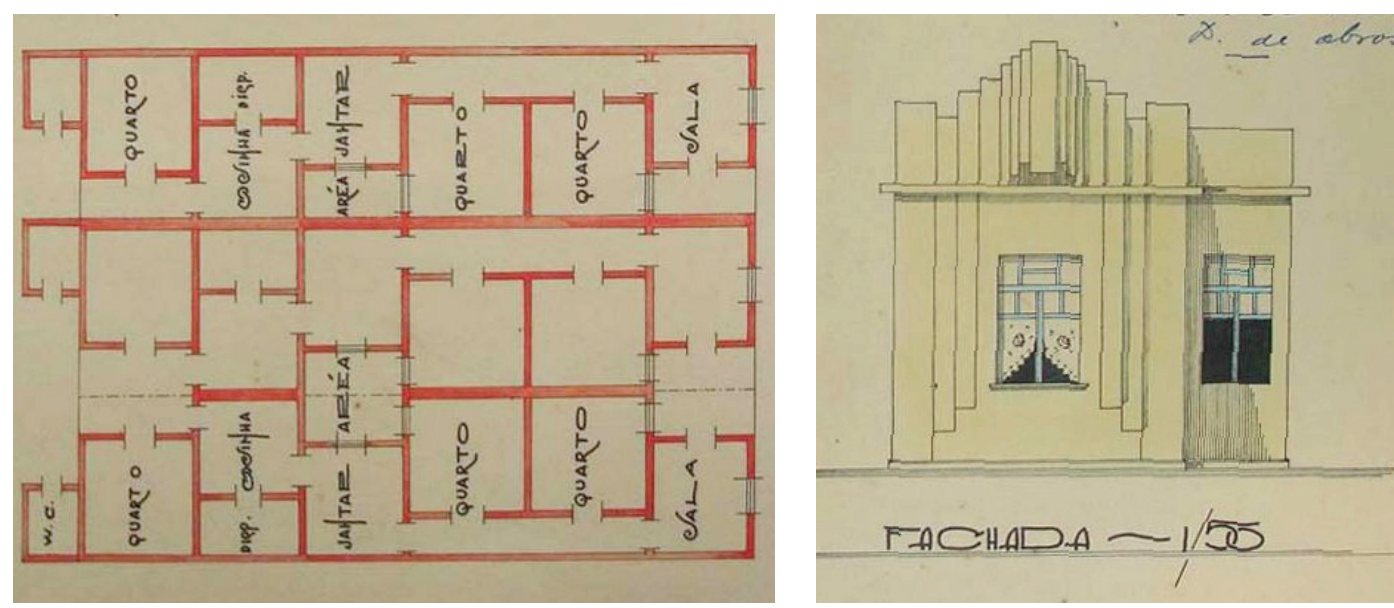

Figura 8: Novos arranjos de planta para atender às exigências por ar e luz. Residências para a rua Afonso Campos, 1934. Fonte: APMCG.

16 Relatório da administração Vergniaud Wanderley apresentado à Câmara Municipal de Campina Grande. Referente ao período de 1 de janeiro a 31 de dezembro de 1936. Disponível no Arquivo Público Municipal de Campina Grande. fechada em si, para o sossego das "boas famílias" da sociedade campinense, nucleares e burguesas.

Os maiores esforços do poder público em modernizar/ higienizar as partes novas e abastadas de Campina Grande ficam muito evidentes no relatório de governo que o prefeito Vergniaud Wanderley apresentou à Câmara Municipal, referente a sua gestão do ano de 1936:

Cumpre observado que, com o zelo que temos desenvolvido em torno das construções, os edifícios moldados nas plantas previamente exigidas, tomam aspectos modernos, destacando-se principalmente nos bairros, e as novas avenidas, tais como João da Mata, Desembargador Trindade, ruas do Prata, Miguel Couto, onde as residencias particulares revelam gosto estético, contrastando com a maior parte dos casarões pesados, sem luz direta, nem condições higienicas, existentes na parte central e primitiva da cidade $^{16}$.

Em considerável número, as classes médias e baixas permaneceram como reféns do mercado de locação. As fileiras de casas construídas pela iniciativa privada para a renda de seus proprietários continuaram surgindo em várias áreas da cidade. Contudo, destinadas ao mercado de locação ou erguidas para a moradia de seu dono, as mudanças nessas habitações não foram tão grandes quanto às trazidas pelas residências mais ricas. Se antes existia um padrão de distribuição espacial considerado perigoso para a saúde dos seus moradores (com a presença das condenadas alcovas e a ausência de latrina), as exigências por ar e luz não tardaram a criar novos modelos de planta para essas habitações, higienicamente corretos (de acordo com os códigos) e exaustivamente repetidos pelos projetistas.

Tais modelos estiveram vinculados, quase sempre, ao lote estreito e comprido. A permanência do lote estreito, ocupado por edificações sem recuos laterais e às vezes frontal (possibilitando, assim, a redução do custo de materiais com o compartilhamento de paredes, instalações hidráulicas e telhados entre várias edificações), era a solução mais econômica para o mercado de locação e a mais rentável para os loteadores. Os problemas de iluminação e ventilação foram resolvidos com poucas mudanças em relação às plantas anteriormente dominantes: as salas frontais perderam um pouco de largura para a inserção de um pequeno acesso lateral, uma espécie de terraço, que permitiu a abertura de janelas para o quarto da frente. Dentro, foram inseridos pequenos poços, às vezes compartilhados por duas casas, para a iluminação da sala de jantar e dos quartos dispostos no miolo da casa, algo não muito distante das soluções de casas econômicas higiênicas construídas em outras cidades do país (figura 8).

Antes dos serviços de saneamento, os banheiros, agora obrigatórios, continuaram predominando nos fundos dos lotes ou das construções, atrás das cozinhas, com restrita comunicação com o interior da residência. Em alguns casos, o cômodo que abrigava a latrina passou a ser construído separado do cômodo destinado ao banho. A latrina era algo sujo, sem a assepsia proporcionada pelas instalações 
17 Solicitação de licença para construção de 10 casas. Zona rural da Av. da Prata. Proprietário Sebastião Raymundo. 1935 (APMCG).

18 Solicitação de licença para construção de vila operária. Proprietário Indústria Têxtil de Campina Grande. Bairro de Bodocongó. 1936 (APMCG).

Figura 9: Mapa de Campina Grande, início dos anos 1960. A cor azul escuro refere-se à área de ocupação da cidade até os anos 1930. Fonte: Serviço Social do Comércio. mecanizadas de água e esgoto, e, portanto, deveria ser separada do ambiente de banho, um espaço para a limpeza do corpo. Nos casos mais elaborados, essas casas ganharam pequenos recuos laterais, geralmente um, e frontal, que passou a abrigar reduzidos jardins.

Não sabemos em qual escala, mas o mercado privado de locação de Campina Grande também se beneficiou, assim como em outros lugares do país, de incentivos fiscais para a promoção da dita habitação higiênica barata. Em 1935, Sebastião Raymundo requereu licença para a construção de dez "pequenas casas na $3^{a}$ zona (rural) da avenida da Prata", solicitando da municipalidade "a isenção de tributos, visto ser habitações para operários, e por ser de justiça"17. Em 1936, a Indústria Têxtil de Campina Grande (Fábrica Bodocongó) pediu licença para a construção de sua vila operária no bairro de mesmo nome, inicialmente com 40 casas. Justificando que se tratava de "um melhoramento urbano e de uma obra de realce para esta cidade, ao mesmo tempo que vem melhorar as condicções de vida do operariado de sua fabrica", reclamou a dispensa da taxa de licença para sua construção ${ }^{18}$.

Os mais pobres foram expulsos para a zona rural, onde poderiam construir ou alugar casas de baixo custo, erguidas em terrenos baratos e sem infraestrutura urbana, livres das normas higiênicas e da exigência por dispendiosos projetos de arquitetura. Com algumas exceções, continuaram reproduzindo, aí, as casas de taipa com poucas condições de salubridade proibidas nas demais regiões da cidade. No decorrer dos anos, o grande número de casas desse tipo começou a formar longos caminhos em direção a reservatórios de água e fazendas do município, dando origem a muitas das principais vias de atuais bairros da cidade. O mapa de 1943 (figura3) (e a infinidade de pedidos de licença para construir casas de taipa nessas áreas) é eloqüente nesse sentido. Observando-o, percebemos que a estrutura urbana campinense da década de 1940 era formada por um núcleo mais denso, correspondente às zonas urbana e suburbana, do qual saíam várias estradas em direção à zona rural, formando diversos braços de construções

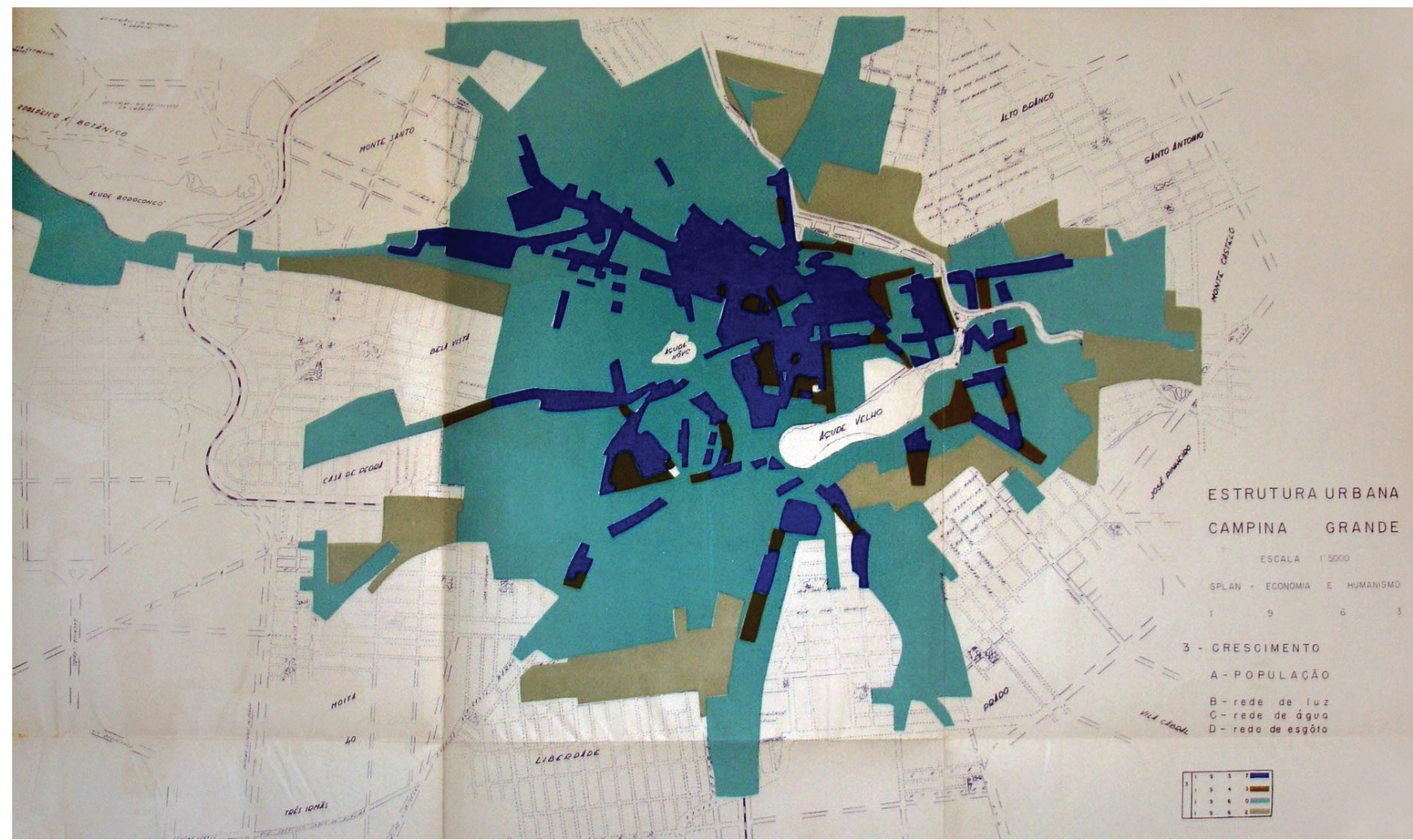


19 Cf. publicação do Serviço Social do Comércio, 196?.

20 Sobre a reforma do ambiente doméstico e suas relações com o gerenciamento do tempo na cidade moderna, ver também o trabalho de Correia (2000).

20 Sobre a reforma do ambiente doméstico e suas relações com o gerenciamento do tempo na cidade moderna, ver também o trabalho de Correia (2000) esparsas. Analisando o mapa do começo dos anos 1960, vemos que os espaços entre esses braços foram completamente preenchidos por iniciativas individuais ou por loteamentos particulares, abertos irregularmente $^{19}$ (figura 9). Assim, na ausência da efetivação de um plano urbanístico que pensasse o conjunto da cidade, acreditamos que esse processo de exclusão e de crescimento desordenado para a zona rural foi um dos mais fortes definidores da forma radiocêntrica atual da trama urbana de Campina Grande. Caminhando, hoje, por qualquer uma dessas ruas ou bairros, observando suas casas, lotes e implantações, as heranças desse processo de expansão urbana nos parecem muito evidentes.

\section{Água e esgoto em domicílio}

Além da necessidade de ar, luz e latrina, a instalação dos serviços de saneamento pelo Escritório Saturnino de Brito, em 1939, também promoveu alterações importantes nas construções campinenses atendidas pela rede. Os espaços domésticos e as interações estabelecidas entre as pessoas, as suas casas e a cidade foram redefinidos. A precária infra-estrutura urbana anterior impossibilitava a multiplicação e a correta utilização de instalações hidráulicas mecanizadas em cozinhas, banheiros e demais espaços dependentes de água e produtores de esgoto, como notou o engenheiro José Fernal na sua palestra de 1938 no Rotary Clube da cidade:

Notais o máu cheiro desprendido nos gabinetes sanitários proveniente das fossas mal feitas, como referi a pouco. Por isso, elas são quasi sempre no extremo das casas ou nos quintais. Os defeitos da construção do proprio gabinete sanitário e a deficiencia de agua para a lavagem dos W.C., ou sejam aparelhos improprios, canalisações de barro de feira com junta vasando, falta quasi absoluta de tubos ventiladores e muitas vezes insuficiencia de área de luz diréta, até com ausencia de janela, são ainda outros perigos á saúde (FERNAL, 1938, p.6).

Limitação de água, aparelhos (bacias sanitárias) impróprios, canalização de barro de feira com junta vazando, falta de tubos ventiladores e ausência de ar e luz criavam banheiros que eram um "perigo para à saúde", colocados, com todos os seus odores, "no extremo das casas ou dos quintais". Contra esse quadro, os serviços de saneamento, além de resolverem o problema da escassez de água do município, deveriam agir no sentido de prover a cidade de instalações técnicas capazes de proporcionar a difusão não só de gabinetes higiênicos individualizados para cada habitação, com a utilização de bacia sanitária com descarga, mas também a disseminação de pontos de esgoto em cozinhas e áreas de serviço e de torneiras com água corrente para a execução das atividades cotidianas, como lavar a louça, as mãos, preparar os alimentos ou tomar um banho. Ficaria mais fácil, assim, ser higiênico, seguir as recomendações das campanhas sanitaristas para a higiene do corpo e da moradia. Como publicou o jornal A União de 19 de janeiro de 1939, a população "imediatamente beneficiada com a prodigiosa transformação [do saneamento], sabe, porém, em que proporções ela lhe vem derimir dificuldades, sinão verdadeiros sofrimentos, modificar hábitos" (SANEAMENTO..., 1939).

Como aponta Beguin (1991, p.50) para o caso da Inglaterra, a água e a coleta de esgoto em domicílio deram uma função prática à arquitetura, pois facilitaram a realização dos gestos domésticos, principalmente os da limpeza da casa. Ainda segundo o autor, a água corrente domiciliar permitiu ganhar tempo, economizar forças, evitar o caminho que seria preciso percorrer para buscar água fora. Seriam essas economias de tempo ${ }^{20}$, de energia e de tensões que desenhariam a rampa onde se poderia fazer escorregar o pobre em direção a outros comportamentos; não proibindo nada, mas substituindo o que servia de suporte aos maus hábitos por um ambiente que consolidasse os bons hábitos. Mais água, um interior fácil de limpar, aerar e aquecer; isto abriria caminhos para novas práticas (BEGUIN, 1991, p.48). “A Idéia Sanitária, eixo do que se poderia considerar um começo de política habitacional", procurou "atingir o íntimo das pessoas por meio da redefinição do espaço da casa, organizado de maneira a que seus ocupantes desenvolvessem hábitos civilizados" (BRESCIANI, 1992, p.16-17).

No caso de Campina Grande, pelo menos para as construções ligadas ao maquinário urbano de saneamento, minoritariamente pobres, não seria mais necessário armazenar a água em cisternas, comprá-la dos aguadeiros ou transportá-la em baldes de quintais para cozinhas e banheiros, nem jogar os esgotos em fossas ou armazená-los em barris, 
21 O Regulamento de Construção de 1938 da capital paraibana chegou mesmo a dizer que "na zona urbana, contudo, será permitida a construção de taipa e telha em ruas em que não possuam rêde de saneamento" (JOÃO PESSOA, 1958).

22 Ver Decreto No. 1.372 no jornal A União de 11 ago. 1939.

23 A mecanização das instalações hidrossanitárias das cozinhas foi um processo que ocorreu paralelamente a uma série de outros avanços na preparação das refeições, como o surgimento do fogão a gás e a evolução da indústria alimentícia e de eletrodomésticos. Tudo isso tinha como intuito reduzir o tempo com os afazeres domésticos, liberando a mão de obra feminina para o trabaIho externo (CORREIA, 2000, p.26). Para a mecanização do espaço doméstico, ver também Giedion (1978). para depois serem despejados nos logradouros públicos do município. Os serviços de saneamento tornariam os hábitos higiênicos mais confortáveis, promoveriam novas sensações de bem-estar, que, uma vez vivenciados, tornar-se-iam irrecusáveis. Depois de experimentado, quem abriria mão de um banho de chuveiro? Como noticiou o jornal Voz da Borborema, o saneamento traria "o conforto e a hygiene para assegurarem um novo padrão de vida aos abastados, e, muito mais aos nossos habitantes pobres" (ABASTECIMENTO..., 1937). Para a maioria destes, o conforto e a higiene não seriam "muito mais", pois as redes de água e esgoto não chegariam em seus domicílios. Algum conforto, é verdade, seria proporcionado pelos vários chafarizes de água potável distribuídos pelos bairros da cidade, mas nunca comparado com as comodidades trazidas pelas instalações domiciliares. Nas casas mais pobres e marginais, provavelmente nada mudou ${ }^{21}$. De qualquer forma, em cada caso na sua medida, estabelecer-se-ia uma relação de dependência entre as pessoas e os novos agentes urbanos da higiene.

Em janeiro de 1939, "várias residências e casas de trabalho, sobretudo das construções recentes", estavam "aparelhadas para o sistêma dagua e esgôto a estabalecer-se" (SANEAMENTO..., 1939). Câmara (1947, p.130) fala que 30 construções possuíam ligação domiciliar nesse momento. Com o passar dos meses, esse número foi aumentando, atingindo todo o perímetro atendido inicialmente pela rede. Para a instalação dos serviços em suas edificações, os proprietários deveriam apresentar projeto hidrossanitário para a apreciação e aprovação da Repartição de Saneamento da cidade. Era uma forma de orientar e controlar o aparelhamento das edificações para as redes mecanizadas de água e esgoto, garantindo a eficácia do funcionamento de todo o sistema. O projeto teria que ser elaborado pelo setor técnico da própria repartição ou por profissional licenciado por esse órgão e habilitado pelos conselhos regionais de engenharia e arquitetura, conforme determinava o decreto $\mathrm{N}^{\circ}$. 1.372, de 30 de março de $1939^{22}$

Com a conexão dos domicílios e dos demais estabelecimentos às redes de água e esgotos, foi introduzido e difundido para maior número de construções todo um aparato técnico que permitiu o pleno funcionamento desse maquinário urbano de saneamento: canalização, lavatórios, torneiras, chuveiros, bacias sanitárias, sifões, hidrômetros. Além de banheiros, a mecanização na adução de água e na eliminação dos esgotos atingiu cozinhas, áreas de serviço, jardins. Em conseqüência, as espacializações foram alteradas. O avanço das instalações hidrossanitárias, com a possibilidade de uso de bacias sanitárias com descarga e a conseqüente eliminação imediata dos dejetos de dentro do edifício, viabilizou a multiplicação dos banheiros e o seu acesso ao interior do espaço doméstico. Pias com torneira foram colocadas em cozinhas $^{23}$ e áreas de serviço, copas e salas de jantar ganharam lavatórios. Ao apresentar o projeto hidrossanitário, muitos proprietários já o faziam com diversas alterações na espacialização de suas residências, modificando a localização de cozinhas e banheiros, para deixá-los mais integrados com os demais ambientes da casa (figuras 10 e 11).

As buscas pela circulação de ar, pela incidência de luz solar, por água corrente e potável e por esgotos tratados e distantes dos espaços de convívio e de circulação das pessoas promoveram alterações significativas nas formas de produção das construções e do espaço urbano das cidades engajadas no processo de modernização de suas estruturas. A edificação afastada do(s) limite(s) do lote, o rearranjo das plantas para a inserção de aberturas para o exterior, a introdução de jardins e todas as transformações sofridas pelas construções diante das redes de saneamento foram importantes definidores na ruptura dos padrões urbanísticos de herança colonial dominantes nos centros urbanos brasileiros entre os oitocentos e início dos novecentos. Desse modo, através do caso do município do interior paraibano, fica evidente o alcance e as conseqüências dos discursos e das políticas higienistas pelo território nacional, assim como o seu vínculo à ascensão e à legitimação de um corpo técnico profissional formado por engenheiros, médicos, arquitetos e urbanistas.

\section{Referências bibliográficas}

ABASTECIMENTO d'água e saneamento de Campina Grande. Jornal Voz da Borborema, Campina Grande, 28 jul. 1937

ALUGUERES de casas. Jornal Brasil Novo, Campina Grande, 7 mar. 1931 

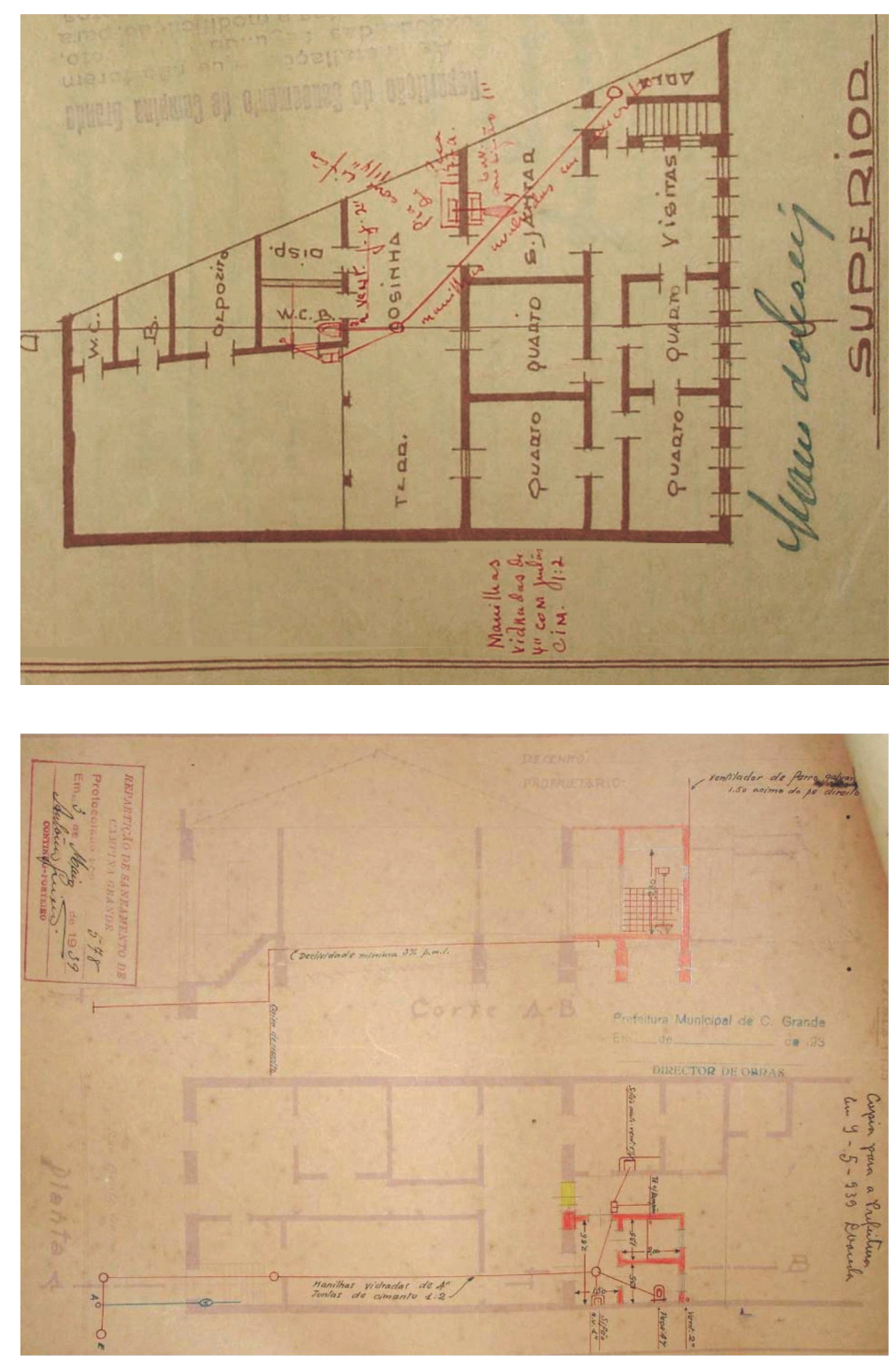

Figuras 10 e 11: Aparato técnico introduzido nas construções para possibilitar o perfeito funcionamento das redes mecanizadas de abastecimento de água e coleta de esgoto. Esquerda, solicitação para saneamento da casa de Francisco Maria. Rua Alexandrino Cavalcanti, 1939. Direita, solicitação para saneamento de casa na rua Bento Viana, 1939. Fonte: APMCG.
AGRA, G. F. A urbs doente medicada: a higiene na construção de Campina G(g)rande. Campina Grande: Gráfica Marcone, 2006.

ANDRADE, C. R. M. O plano de Saturnino de Brito para Santos e a construção da cidade moderna no Brasil. Espaço e debates, São Paulo, n.34, p.55-63, 1991.

A Peste e o Plano: o urbanismo sanitarista do engenheiro Saturnino de Brito. Dissertação (Mestrado) - Faculdade de Arquitetura e Urbanismo, Universidade de São Paulo, 1992.

BARBEARIA Popular. Jornal O Campina Grande, Campina Grande, 11 jul. 1909.

BEGUIN, F. As máquinas inglesas do conforto. Espaço e debates, São Paulo, n.34, p.39-54, 1991.

BONDUKI, N. Origens da habitação social no Brasil: arquitetura moderna, lei do inquilinato e difusão da casa própria. São Paulo: Estação Liberdade/ Fapesp, 1998.

BRESCIANI, M. S. M. Permanência e ruptura no estudo das cidades. In:FERNANDES, A.; GOMES, M. A. A. F. Cidade \& História: modernização das cidades brasileiras nos séculos XIX e XX. Salvador: UFBA/Mestrado em arquitetura e urbanismo/ANPUR, 1992.

BRITO, S. Urbanismo: traçado sanitário das cidades. Rio de Janeiro: Imprensa Nacional, 1944.

CAIXAS de phosphoros. Jornal Brasil Novo, Campina Grande, 14 fev. 1931.

CÂMARA, E. Datas campinenses. João Pessoa: Departamento de publicidade, 1947 (Reimpressão de 1998 pela Editora Caravela).

CONFEITARIA Petropolis. Jornal Voz da Borborema, Campina Grande, 16 jul. 1937. 
CONGRESSO pan-americano da vivenda popular. Arquitetura e urbanismo, Rio de Janeiro, p.67, nov-dez. 1939.

CONGRESSO pan-americano de arquitetos. Arquitetura e urbanismo, Rio de Janeiro, n.2, p.13-35, mar-abril 1940.

CORREIA, T. B. A gestão do tempo e a organização da cidade moderna. Revista Sinopses, São Paulo, n. 33, p.22-32, jun. 2000

A construção do habitat moderno no Brasil 1870-1950. São Carlos: Rima, 2004

DIRECTORIA Geral de Saúde Pública. Jornal A União, João Pessoa, 18 jan. 1935

FERNAL, J. Saneamento de Campina Grande. Campina Grande: Rotary Clube de Campina Grande, 1938

GIEDION, S. La mecanización toma el mando. Trad. Esteve R. Suari. Barcelona: Gustavo Gili, 1978.

HOCHMAN, G. A Era do Saneamento: as bases da política de saúde pública no Brasil. São Paulo: Hucited ANPOCS, 1998.

HOTEL CENTENÁRIO. Jornal O Século, Campina Grande, 14 jul. 1928.

HOTEL CENTRAL. Jornal A Batalha, Campina Grande, 4 abr. 1935

HOTEL DOS VIAJÂNTES. Jornal O Campina Grande, 2 maio 1909.

HOTEL PERNAMBUCANO. Revista Era Nova, Parahyba do Norte, n.25, 1 maio 1922

KROPF, S. P. O saber prever, a fim de prover: a engenharia de um Brasil moderno. In: HERSCHMANN, M. M.; PEREIRA, C. A. M. A invenção do Brasil moderno: medicina, educação e engenharia nos anos 20-30. Rio de Janeiro: Rocco, 1994.

JOÃO PESSOA. Regulamento de Construções do Município de João Pessoa. Decreto $N^{\circ} .399$, de 21 de setembro de 1938. In: DELORENZO NETO, A. A codificação municipal de João Pessoa. Rio de Janeiro: Serviço de documentação, 1958.

LE CORBUSIER. A carta de Atenas. São Paulo: HUCITEC/ EDUSP, 1993.

MANOEL. S. K. Fundação da casa popular (1946-1964): projeto frustrado de construção de uma política habitacional no Brasil. Dissertação (Mestrado) - Departamento de Arquitetura e Urbanismo da Escola de Engenharia de São Carlos, Universidade de São Paulo, São Carlos, 2004

PALACE HOTEL. Revista Era Nova, Parahyba do Norte, n.29, 1 jul. 1922

PARAISO para as "mulheres dadeiras". Jornal O Século, Campina Grande, 2 mar. 1929.

PRECAUÇÕES para evitar as febres typhoide e paratyphoide. Jornal A União, João Pessoa, 16 jan. 1935

ROSSI, L. M. Art Déco sertanejo. Design \& Interiores, São Paulo, n.41, 1994.

SABÃO Higyenico Protector. Jornal O Século, Campina Grande, 13 out. 1928

SANEAMENTO de Campina Grande. Jornal A União, João Pessoa, 19 jan. 1939.

SERVIÇO SOCIAL DO COMÉRCIO. Campina Grande: um centro comercial do Nordeste. SESC Departamento Nacional, 196?.

VALET Auto Strop. Jornal O Século, Campina Grande, 8 set. 1928. 


\title{
Buildings with air, lighting, water and sewage: hygiene and housing production in Campina Grande (PB) of 1930-1950
}

Marcus Vinicius Dantas de Queiroz

\begin{abstract}
This project studies how hygienist discourses and practices guided housing production and redefined the home environment in the city of Campina Grande (PB) during the 1930s and 1940s. Investigates how the sanitary codes' demands for air and light inside the buildings and the insertion of urban sanitation machinery established new ways for projects development and contributed to the legitimacy of the engineering, architect and urban planner professions before the Brazilian society of the 1930s. Based on the case study of the state of Paraíba, seeks to understand the health and housing scope policies rising in this new state.
\end{abstract}

Keywords: housing production, hygiene, Campina Grande (PB).

\section{Construcciones con aire, luz, agua y agoto: higiene y producción habitacional en la Campina Grande (PB) de los 1930-1950}

Marcus Vinicius Dantas de Queiroz

\section{Resumen}

Estudia como discursos y prácticas higienistas guiaronlaproducción habitacional y redefinieronel ambiente doméstico enlaciudad de Campina Grande (PB) de las décadas de 1930 y 1940. Investiga como lasexigencias de los códigos sanitarios por aire y luz enel interior de lasconstrucciones y lainsercióndel maquinário urbano de saneamientoestablecieronnuevasdirectrices para elejercicioprojetual y contribuyeron para la legitimação de lasprofesiones de ingeniero, arquitecto y urbanista ante lasociedadbrasileña de losaños 1930. A través delestudio de caso delmunicipiodel interior de la Paraíba, busca comprenderla cobertura de las políticas sanitarias y habitacionales vigentes enel Estado Nuevo.

Palabras clave: producción habitacional, higiene, Campina Grande (PB). 